\title{
The Neglected History of FuRü' and THE Premodern/Modern Binary
}

\author{
Marion Katz \\ New York University
}

\begin{abstract}
Marion Katz reflects on major developments in Islamic legal studies since the 1990's, the decade that saw - as noted in the introduction to this Roundtableexpanded and diversified scholarly attention to Islamic legal studies. For her, it is puzzling then that outdated frameworks continue to percolate in the field, such as the crude "premodern / modern binary" and the continued neglect of what she calls fiqh studies. Katz urges scholars to pursue more nuanced approaches to deal with the sheer volume of the textual corpus and to fill in chasmic history of substantive law, namely: (1) the study of "core samples," that is, the diachronic investigation of individual concepts and doctrines to document inflection points, and (2) the study of "transverse slices," that is, the synchronic study of a wide range of material from a specific historical context that helps expose underlying and pervasive assumptions behind a broad area of law.
\end{abstract}


$\mathrm{W}$ ithout a doubt, the single greatest change in the field of Islamic legal studies since my days as a graduate student in the 1990s is its sheer magnitude. This includes an enormous diversification of its disciplinary methods, institutional locations, and chronological and geographic scope. I'll reflect here only on developments in my own area of study - roughly, pre-Ottoman fiqh-while acknowledging that it (rightly) occupies an increasingly modest fraction of a swiftly growing field. The expansion of what I'll call "fiqh studies" - the academic study of Islamic law as a normative system-applies both to primary-source materials (which have been made accessible on an unprecedented scale in the form of published editions, digitally imaged manuscripts, and searchable online databases) and to secondary studies, which now appear yearly in quantities defying the capacities of any individual scholar.

Like any other interpretive enterprise, Islamic legal history involves a hermeneutic circle in which scholars construct their accounts of long-term developments by aggregating scholarly findings about individual thinkers and texts, while their interpretations of individual thinkers and texts are in their turn informed by their understanding of long-term developments. The increased pace and volume of recent scholarly production has propelled this cycle ever faster. One need only think of a figure such as al-Māwardī (d. 450/1058) to realize how much deep readings of individual works have contributed to the revision of received master narratives, and vice versa. His work alAhkām al-sultān̄ìya is a basic building block in all accounts of the development of what may be termed "constitutional" fiqh, but scholars have offered sharply contrasting interpretations of that work based on their interpretations of the larger legal trajectory in which al-Māward̄̄ was intervening. ${ }^{1}$

1 On al-Māwardī's al-Aḥām al-sulțānīya see, for instance, Frank E. Vogel, "Tracing Nuance in Māwardī's al-Ahkāmal-sultāniyyah: Implicit Framing of Constitutional Authority," in Islamic Law in Theory: Studies on Jurisprudence in Honor of Bernard Weiss, eds. A. Kevin Reinhart and Robert Gleave (Leiden: Brill, 2014), 331-59; Ovamir Anjum, Politics, Law and Community in Islamic Thought: The Taymiyyan Moment (New York: Columbia University Press, 2012), 117-21; Patricia Crone, God's Rule: Government and Islam (New York: Columbia University Press, 
Nevertheless, overgeneralized and outdated frameworks persist to some extent. As Sohaira Siddiqui has discussed in a recent contribution to this series, work in the field is still dominated (in some cases implicitly and structurally, in others overtly) by a dichotomy between "pre-modern/pre-colonial" and "modern/ post-colonial" eras. While her focus is on the ways in which this dichotomy tends to elide the colonial period that intervenes between the two, I'd like to focus here on its implications for the study of "pre-modern" Islamic law. I should begin with the disclaimer that in some contexts, I too use this term as a shorthand acknowledging the comparative continuity of fiqh frameworks prior to the late nineteenth century. Nevertheless, problems arise when such convenient shorthands come to structure and inform our inquiry, providing our guideposts through the everexpanding source base.

Recent years have seen a number of studies that both disaggregate different aspects and stages of legal change in modernity and identify major transformations occurring in earlier centuries (the work of Guy Burak ${ }^{2}$ and Samy Ayoub ${ }^{3}$ comes to mind). Perhaps unsurprisingly, the gradually emerging longue durée narrative of legal history has gained its clearest lineaments in the areas most closely linked to political history. For instance, a development like the Mamlūk institution of chief justices from the four schools of law is a datable event with clear implications for the operation of madhhab-based law in a specific geographical area. As scholars including Patricia Crone, Ovamir Anjum and Mona Hassan ${ }^{4}$ have shown, developments in constitutional law can also be meaningfully linked to the course of political

2004), 232-34. Vogel's contention that Māwardī is not making deep concessions to necessity but asserting novel claims to scholarly authority over statecraft vividly illustrates how continuing debates over long-term developments can lead to contrasting readings of individual texts.

2 Guy Burak, The Second Formation of Islamic Law: The Hanafi School in the Early Modern Ottoman Empire (New York: Cambridge University Press, 2015).

3 Samy Ayoub, Law, Empire, and the Sultan: Ottoman Imperial Authority and Late Hanafi Jurisprudence (New York: Oxford University Press, 2020).

4 In addition to the works of Crone and Anjum in Footnote 1 above, see Mona Hassan, Longing for the Lost Caliphate: A Transregional History (Princeton: Princeton University Press, 2017). 
events. However, this is much less true of developments in other areas of substantive law. Even the most excellent surveys of the field-Hallaq's magisterial Sharí 'a: Theory, Practice, Transformations (Cambridge: Cambridge University Press, 2009) would be one example-often situate their overviews of fiqh's substantive content in a timeless "pre-modern" or "classical" space, to be followed by a discussion of the ruptures of modernity.

The occurrence of legal change is now universally acknowledged, but the focus is often on moments of rupture and conflict rather than on gradual and structural change. It is not without reason that scholars often focus on key crises and disputes. An episode like Ibn Taymīya's (d.728/1328) insistence on the revocability of fourfold divorce in the shadow of incarceration is not only dramatic in itself, but illuminates far broader dynamics. ${ }^{5}$ Arguably, however, there is a sense in which doctrines or conventions that prevailed broadly over a sustained period are more significant than the "creative" or disruptive arguments that made more waves. These broader patterns and more gradual shifts are discernible only through painstaking analysis of lengthy texts with little surface appeal. This may explain the relative paucity of studies focusing systematically on furü ' works. Generally lacking the obvious intellectual appeal of $u s ̦ \bar{l} l$ texts and the contextual color of their sexier cousin the fatwa collection, furü 'compendia have been comparatively neglected in the secondary literature, more often treated as reference works than as objects of study in their own right. Based on their sheer voluminousness (and probably on the degree to which they were historically taught and consulted), fur $\bar{u}$ ' works proportionately constitute the most under-studied genre in the study of Islamic law. Of course, it is in large part this very voluminousness that deters their systematic study.

How can scholars chart a course through this sea of texts? It seems to me that the two most obvious options are what might be called the "core sample" and the "transverse slice." In

$5 \quad$ See Yossef Rapoport, Marriage, Money and Divorce in Medieval Islamic Society (Cambridge: Cambridge University Press, 2005), ch 5 (pp. 89-110). 
this metaphor, the "core sample" is like the columns, narrow in diameter but sometimes literally miles in depth, that scientists bore from the polar ice caps. Samples drawn from different points along the length of such a column can reveal environmental changes that took place over vast periods of time. A "core sample" of the fur $\bar{u}$ ' literature would be a study following a tightly focused legal issue diachronically over a lengthy period. Examples of this approach include Baber Johansen's work on land tax, ${ }^{6}$ Khaled Abou El Fadl's Rebellion and Violence in Islamic Law (Cambridge: Cambridge University Press, 2001), Behnam Sadeghi's The Logic of Law-Making in Islam: Women and Prayer in the Legal Tradition (Cambridge: Cambridge University Press, 2012), and Nurit Tsafrir's Collective Liability in Islam: The 'Áqila and Blood Money Payments (Cambridge: Cambridge University Press, 2019); I have also attempted this type of study in the first half of Women in the Mosque (New York: Columbia University Press, 2014). By tracing the course of a single doctrinal point meticulously over a long period of time, one can hope to craft a narrative in which the inflection points emerge from the specific evidence at hand, rather than being imported from a prior framework (such as dynastic history) that may or may not be illuminating. This approach is complicated by the fact that, unlike a core sample of polar ice, our textual corpus does not generally allow us to hold steady all variables other than time. Doctrinal diversity, geographical shifts in the foci of textual production, and the evolving relationships among various legal and law-adjacent genres all complicate any effort to craft a unitary long-term narrative of development, even on a single legal issue.

In contrast with the "core sample," the "transverse slice" would be a broad and systematic analysis of material from a specific historical context. A study of this kind would address the underlying logic and prevailing assumptions of a broad area of the law and/or of the substantive legal work of a specific author.

6 Baber Johansen, "Legal Literature and the Problem of Change: The Case of Land Rent," in Contingency in a Sacred Law: Legal and Ethical Norms in the Muslim Fiqh (Leiden: Brill, 1999), 446-64. 
It is notable that much more work of this kind has been done in $u s ̧ \bar{u} l$ than in fur $\bar{u}^{\prime}$. In terms of studies of specific thinkers, to the best of my knowledge, there is no fur $\bar{u}$ ' counterpart of Bernard Weiss's work on al-Āmidī̄ or Sohaira Siddiqui's work on al-Juwayn $\overline{1}{ }^{8}$ This may be because fur $\bar{u}{ }^{\prime}$ works are assumed to be less expressive of an author's distinctive intellectual and religious perspective; however, works like al-Juwaynī's Nihāyatal-mațlab, al-Sarakhsī's Mabsūṭt, or Kāsān̄̄'s Badā'i al-șanā 'i could richly reward this kind of inquiry. Just as $u s \underline{u} l$ works are now taken seriously as works of Islamic thought independently of their role as algorithms for the generation of legal doctrine, furu works can similarly be seen as rich mines of social and religious reflection.

In terms of systematic readings of broad areas of the law, the works of Baber Johansen offer a deep exploration of several areas of Hanafī fiqh (with a particular focus on the work of al-Sarakhsī). His work has contributed to subsequent studies including Kecia Ali's Marriage and Slavery in Early Islam (Cambridge: Harvard University Press, 2010), a meticulous analysis of the logics informing several intersecting areas of fiqh. While Ali's book helped stimulate further scholarship on thematically adjacent topics (such as Hina Azam's Sexual Violation in Islamic Law: Substance, Evidence, Procedure [New York: Cambridge University Press, 2015], which deals with overlapping issues of bodily self-ownership) it is surprising how little her methodology has informed subsequent studies in other areas of fur $\bar{u}^{\prime}$. This may bespeak the tendency for work dealing with women or gender to be relegated to its own niche, rather than regarded as integral to the wider field.

$7 \quad$ Bernard Weiss, The Search for God's Law: Islamic Jurisprudence in the Writings of Sayf al-Dīn al-Āmidī (Salt Lake City: University of Utah Press, 1992).

8 Sohaira Siddiqui, Law and Politics under the Abbasids: An Intellectual Portrait of al-Juwayni (Cambridge: Cambridge University Press, 2019). Here I'm thinking primarily of works analyzing the substantive doctrinal content of a fur $\bar{u}^{\prime}$ work rather than its methodological approach; examples of the latter include Talal Al-Azem, Rule-Formation and Binding Precedent in the Madhhab-Law Tradition: Ibn Quțlūbughā's Commentary on the Compendium of Qudūrī (Leiden: Brill, 2017) and Umar F. Abd-Allah Wymann-Landgraf, Mãlik and Medina: Islamic Legal Reasoning in the Formative Period (Leiden: Brill, 2013). 
It is by accumulating a larger repertory of diachronic "core samples" and synchronic "transverse slices" we can begin to fill in the history of substantive law. (Some works, like Azam's Sexual Violation, can also be hybrids of the two.) It is true that many people are already using variations of a rough periodization into "formative," "classical," and "pre-classical" periods, but we have few thorough accounts of the evolution through these periods for specific legal issues. Until we do, we may run the risk (or face the necessity) of falling back on the fiction of a timeless "premodern" fiqh. This phenomenon has been evident in the reception of Ali's book; itself rigorously based on sources of the formative period (roughly, the third/ ninth century), it is sometimes taken to describe a synthesis disrupted only by the transformations of modernity. For instance, even an excellent study such as Kenneth Cuno's Modernizing Marriage draws in part on Ali's findings to inform his account of the "precolonial" conceptions of marriage that were displaced by Egyptian reforms of the late nineteenth and early twentieth century. ${ }^{9}$

In addition to over-generalization of findings on the formative period, there are also instances where the received wisdom on "pre-modern" fiqh is extrapolated back from analyses of modern developments. This can sometimes be seen in the broader reception of the work of Talal Asad, who has so meticulously reconstructed the discursive transitions of the colonial period. As Khaled Fahmy has recently observed, Asad's arguments about the "transmutation of shari'a" are based on close reading of "legal texts from the very last years of the late nineteenth and early twentieth century." 10 It is obvious that contrasts constructed on the basis of evidence from the nineteenth and twentieth century cannot be projected backward

9 Kenneth Cuno, Modernizing Marriage: Family, Ideology, and Law in Nineteenth and Early Twentieth-Century Egypt (Syracuse, NY: Syracuse University Press, 2015), 2, 87. Cuno does acknowledge the diversity of Islamic normative discourses on marriage and strives to be attentive to change over time.

10 Khaled Fahmy, In Quest of Justice: Islamic Law and Forensic Medicine in Modern Egypt (Berkeley: University of California Press, 2018), 24. Fahmy's own proposal is to turn away from Asad's focus on discourse, but this observation applies just as well to the study of discourses. 
into the deep past, and this was certainly not Asad's intention. However, hypotheses about what is new and distinctive in modern developments are sometimes taken to imply a durable or even timeless status quo ante. For instance, to again quote Fahmy, Asad "traces transmutations of the concepts of the individual and the family and studies how these transmutations brought about a distinction between morality and law." 11 The implication could be drawn that prior to the modern period there was no such distinction. However, other evidence from the late nineteenth and early twentieth century has been taken to imply an opposite trajectory, towards an unprecedented modern synthesis of Islamic law and ethics. Examining the new roles of Deobandi ' $u l a m \bar{a}$ ' in British-ruled India, Brannon Ingram argues that while "[f]atwas were traditionally solicited by kazis," in the late nineteenth and early twentieth centuries " $[t]$ he fatwa became a tool of mass moral reform, 'a form of the care of the self,' linking 'selves to the broader practices, virtues, and aims' of Islamic tradition." ${ }^{\prime 2}$ Did modernity bring an unprecedented rupture between "morality and law" (as suggested by Asad) or an unprecedented synthesis between the two (as suggested by Ingram)? Only a richer account of premodern developments, not extrapolation from developments in modern sources, can answer this question.

My own current research on the fiqh of wives' domestic labor is structured as a series of "transverse slices" focusing on how this issue fits into the broader legal logic of a series of jurists. Perhaps unsurprisingly, these snapshots suggest that there is a more complicated trajectory to be reconstructed between the model of the marriage contract Ali established for the formative period and the modern transitions documented by scholars like Cuno. Wives' domestic labor was also an issue where scholars

11 Ibid., 24.

12 Brannon D. Ingram, Revival from Below: The Deoband Movement in Global Islam (Oakland: University of California Press, 2018), 48. Here Ingraham is citing Hussein Ali Agrama, "Ethics, Tradition, Authority: Toward and Anthropology of the Fatwa," American Ethnologist 37 (2010): 4. However, Agrama's own position (like Asad's) seems to be that the contemporary Egyptian fatwās perform this ethical function despite, not because of, their being products of modernity. 
often explicitly perceived a divergence between the legal parameters of the marriage contract (which did not require wives to do housework) and the ethico-religious ideals of wifely conduct (which did). To the extent that there is an overall long-term arc, the evidence suggests that in the discussion of this specific issue the trajectory was towards an unprecedented synthesis between legal and ethical discourses in the modern period. However, the larger takeaway is that there is no valid binary between "premodern" and "modern," if only because the terrain of "premodern" opinion is so diverse and its progress so far from unidirectional. 